\title{
Ellen Alffest'in Eserlerinde Öne Çıkan Yaklaşımlar: Temsiliyet ve Psikolojik Etkiler
}

\author{
Öğr. Gör. Evrim ÖZESKici \\ Uşak Üniversitesi \\ GSF, Resim Bölümü \\ evrimozeskici@gmail.com \\ ORCID: 0000-0003-1491-3487
}

\begin{abstract}
Öz
Ellen Altfest'in eserleri incelendiğinde; temsil kavramının ve psikolojik etkilerin öne plana çıktığı gözlemlenmiştir. Araştırmanın amacı; Ellen Altfest'in eserlerindeki detaylandırmaların ve hiperrealist aktarımların nasıl geliştiğini incelemektir. Aynı zamanda benzer üslup yönelimi olan sanatçılar ile Ellen Altfest'in eserleri karşılaştırılarak; temsil olgusunun altında yatan gerekçeleri ortaya çıkarmaktır. Araştırmada Ellen Altfest'in eserleri ile Praksiteles'in Knidos Afroditi, Lucian Freud'un Ayvalar ve Yaprakları ile Kı, Chuck Close'un James isimli eserleri karşılaşıırma yapılmıştır. Seçilen bu sanatçılar ve eserleri; araştırmanın kapsam ve konusunu oluşturmaktadır. Araştırmanın problemleri şu şekilde sıralanabilir: Ellen Altfest'in eserlerinde öne çıkan temsiliyetin ve psikolojik etkilerin gerekçeleri nelerdir? Araştırmaya konu olan sanatçılar, eserlerinde temsil olgusunu nasıl ele almışlardır? Sanatta temsil olgusunun; kavramsal ve anlamsal bir ilişkisi var mıdır? Ellen Altfest'in eserlerindeki detaylandırmanın kavramsal bir açıklaması var mıdır? Seçilen sanatçılar ile Ellen Altfest'in eserleri arasındaki farklııklar nelerdir? Bu soruların cevapları; Ellen Altfest'in eser çözümlemelerine ve sanatta temsil olgusuna açıklık getireceği umulmaktadır.
\end{abstract}

Anahtar Kelimeler: ellen altfest, temsiliyet, psikolojik etkiler, hiperrealist aktarımlar

Özeskici, E. (2020). Ellen Altfest'in Eserlerinde Öne Çıkan Yaklaşımlar: Temsiliyet ve Psikolojik Etkiler. ARTS: Artuklu Sanat ve Beşeri Bilimler Dergisi, 3, ss. 99-116. 


\title{
Prominent Approaches in Ellen Alffest's Works: Representation and Psychological Impacts
}

\begin{abstract}
When the works of Ellen Altfest are analysed, it has been observed that the concept of representation and psychological impacts have become prominent. The aim of the research is to examine how the details and hyperrealist transferences develop in Ellen Altfest's work. In addition, it aims to reveal the truth behind the concept of representation by comparing Ellen Altfest's works with artists who have the same tendencies in style. The research compares Praxiteles's Aphrodite of Knidos, Lucian Freud's Quinces and Girl with Leaves, Chuck Close's James, with Ellen Altfest's works. These selected artists and their works create the scope and theme of the research. The problems in the study can be listed as follows: What are the reasons of representation and psychological impacts that are prominent in Ellen Altfest's works? How have the artists, who are subject to the research, approached the concept of representation in their works? Is there a conceptual and semantic relationship between the concept of representation in art? What are the differences between the selected artists and the works of Ellen Altfest? It is expected that the answers to these questions will clarify Ellen Altfest's analysis of works and the concept of representation in art.
\end{abstract}

Keywords: ellen alffest, representation, psychological influences, hyperrealist transferences 


\section{$\operatorname{arts}=$}

\section{Gíriş}

Ellen Altfest Amerikalı bir sanatçıdır. Eserlerinde yaşamın, doğanın, bedenlerin, taşların, ağaçların ve bitkilerin detaylarını resmeden realist bir sanatçıdır. Alfest'in nesneleri detaylandırmasıyla birlikte iki önemli olgu ortaya çıkmaktadır: İlki temsiliyet, diğeri ise psikolojik etkiler. Temsiliyet; bir nesnenin özelliklerini yansıtmak ve sembolize etmektir. "Temsil, dolaylı ve sembolik bir yapı içinde gerçekliği göreli olarak aktarabilir. Temsil, varlıkların, nesne ve durumların, düşüncelerin ve olguların yerine geçebilecek bir aktarım, bir aracılık durumudur. Dil, sanat ve kültür gibi alanlar aktarım aracılığını üstlenen temsil alanlarından bazılarıdır" (Gök, 2016, s.116).

Bu bakımdan düşünüldüğünde sanatta temsil unsuru; toplumsal yapıya ve dönemin özelliklerine bağlı olarak değişkenlik göstermiştir. Örneğin Arkaik dönemde insan anatomisine bağllık, oran-orantıdaki sağlamlık ve aslına uygunluk önemli bir yer tutar. Bu durum Yunan sanatındaki temsiliyet kavramını açıklamaktadır. Rönesans sanatındaki; Michelangelo' nun Davut ve Pieta heykelleri, Raffaello Sanzio'nun Atina Okulu ve Titian'ın Meryem'in Göğe Kabulü gibi eserler temsil olgusu kapsamında değerlendirilebilir.

Sanatın tarihsel sürecine bakıldığında temsil kavramının gerçek ve gerçek olmayan konular bağlamında eserlere yansıdığı görülür. Praksiteles'in yapmış olduğu Knidos Afroditi bir Tanrıça heykelidir. Mitolojik Tanrı ve Tanrıça heykelleri gerçek değildir; ancak insan silvetine benzerliği ve anatomik sağlamlığı temsil olgusunu doğurur. O halde yapılan bir eserin gerçekle ilişkisi; zihinsel süreçte kodlanan kavramların temsil edilmesiyle mümkündür. Böylece yansıtılan nesneler; hem kavramsal olarak hem de psikolojik olarak etki yaratır. İlk çıplak kadın figürü olan Knidos Afroditi, temsili ve sembolik bir heykeldir.

Bu kapsamda Ellen Altfest'in eserleriyle Knidos Afroditi arasındaki benzerlik; temsili gerçekliktir ve detaylardaki estetik vurgudur. Farklı zamanlarda ve disiplinlerde yapılan iki ayrı eser olmalarına karşın; temel yaklaşımları benzerdir. Heykeldeki kadın figürü, güzel bir kadın imgesidir; aynı zamanda kadın ve bedeni arasındaki estetik olguyu ifade eder. Altfest ise eserlerindeki nesneleri; estetik ve psikolojik bağlamda 
inceler. Dolayısıyla Altfest, eserlerinde zamansal ve uzamsal bir etki yaratarak izleyiciyi psikolojik bir tepkimeye sokar. Bedenleri ve nesneleri detaylandırması; gerçeği daha net ve görünür kılmak için bir yöntemdir. "Ellen Altfest nesnelerin resimlerini yapar -insan veya bitkisel, canlı veya cansız olsunlar - ki o kadar ince detayına kadardır ki, Pluto kadar garip olabiliyorken aynı zamanda avucunuzun içi kadar da tanıdık canlandırlırlar" (Sherlock, 2015, s.177). Bu canlılık, Altfest'in güncel sanatta temsil kavramına ilişkin bir yorumudur. Dolayısıyla her sanatçının temsil kavramına ilişkin yorumu farklılık gösterir.

Temsiligerçeklik, geçmişten günümüze değin sanatın tartışılan kavramlarından birisidir. Ancak gerçeğin görüntüsünü detaylandırarak öne çıkarmak; ayrıntıların daha kavramsal bir nitelik kazanmasına neden olmaktadır. Altfest'in eserleri gerçekçidir; aynı zamanda kavramsaldır. Bu bağlamda sanattaki estetik olguyu, klasik beğeni anlayışından ayrı tutarak yorumlamaktadır. Eserlerindeki yorumlama gerçekliğin ötesinde bir sorgulamaya dönüşerek; izleyici ve eser arasındaki gerilimi artııır. İzleyici hem kendi bedeniyle hem de yaşamıyla yüzleşir; gerçekleri daha ayrıntılı bir şekilde görme fırsatı yakalar.

\section{YÖNTEM}

Araştırmada konun içeriğine uygun olarak literatür taraması yapılmıştır. Konuyla ilişkili olarak yabancı dergilere, kitaplara ve makalelere başvurulmuştur. Ellen Altfest'in eserlerinde öne çıkan temsiliyet ve psikolojik etkiler üzerine kaynak taraması yapılmışırı. Aynı zamanda konunun içeriğine uygun olarak örnek sanatçılar seçilmiş ve Ellen Altfest'in eserleriyle karşılaştırma yapılmıştır.

Araştırmada ilk olarak Estetiğin Değişimi: Knidos Afroditi ve The Back başlığı ile başlanmıştır. Çünkü geçmiş ile güncel sanattaki estetik algı ve temsil olgusundaki yaklaşımlar farkllık göstermiştir. Bu yüzden Praksiteles'in ve Ellen Altfest'in eser örnekleri karşılaştırımıştır.

Lucian Freud'un ve Ellen Altfest'in Eserlerindeki Benzerlikler adlı başlıkta her iki sanatçının eserlerindeki realist aktarımları ile deformasyonları arasındaki benzerlikler 
üzerinde durulmuştur. Sanatçıların eser çözümlemelerinde; nesnelerin kavramsal yapısı incelenmiştir. Ellen Altfest'in eserlerindeki nesneleri nasıl kurguladığı ve anlamlandırdığı açıklanmıştır.

Nesnelerin Temsili: "Taş, Ayak, Bitki", "Koltuk Altı" ve "James" isimli başlıkta ise; Ellen Altfest ile Chuck Close'un eserlerinde öne çıkan yaklaşımlar ve kavramların neler olduğu belirtilmiştir. Dolayısıyla sanatçıları temsil olgusuna iten sebepler açıklığa kavuşturulmuştur.

\section{BULGULAR VE TARTIŞMALAR}

Araştırmanın amacl; Ellen Altfest'in eserlerinde konu edindiği görsellerin psikolojik etkilerini analiz etmektir. Sanatçının realist aktarımıyla psikolojik etkilerin bir bağlantısı olup olmadığını araştırmaktır. Aynı zamanda Altfest'in eserlerinde temsil olgusuna ihtiyaç duymasındaki gerekçeleri ortaya çıkarmaktır. Eserlerinde öne çıkan yaklaşımları açıklamak için alt başlıklar yapılmıştır; sanat tarihinden eser örnekleriyle sanatçının eserleri karşılaştııımıştır. Böylece temsil olgusunun geçmişte ve bugün nasıl ele alındığının; benzer yönlerinin neler olduğunun farkına varılacağı umulmaktadır.

\section{Estetiğin Değişimi: Knidos Afroditi ve The Back}

Zamanın, mekanın ve algının değişimi; izleyicinin sanat eserine olan yaklaşımını belirlemektedir. Sanat tarihindeki en eski uygarlıkların yapmış oldukları eserler ile günümüz sanatındaki eserler arasındaki fark; izleyicinin eser karşısındaki tavrıdır. Bu farkın gelişimi toplumun sanatla olan iletişiminde saklıdır. İzleyicinin eser karşısındaki yorumunu ve etki gücünü belirleyen olgu ise; estetiktir. Bu bakımdan estetik, sanatta en çok değişen ve gelişim gösteren bir kavramdır.

Bu başlıkta; estetiğin değişimini açıklamak için, iki farklı zamanda yapılmış olan eserlerin karşılaştırması ele alınmıştır. Temsil olgusunun ve estetik biçimin zaman içerisinde nasıl bir değişim geçirdiğini anlamak için; Praksiteles' in Knidos Afroditi (M.Ö. 360-330 yılları arasında) ile Ellen Altfest'in The Back isimli eserleri örneklendirilmiştir. 

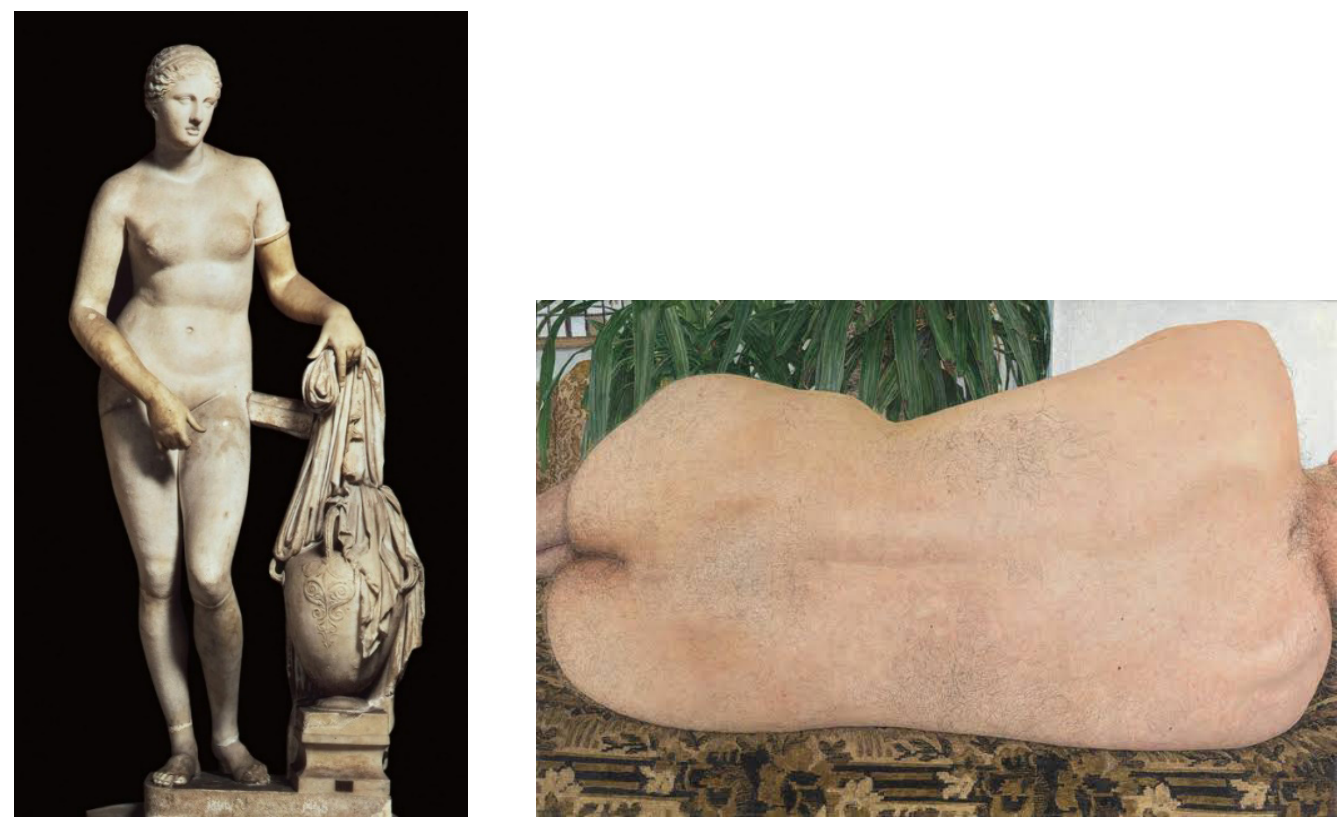

Görsel 1. Praxiteles'in Knidos Aphroditesi, M.Ö. 360-330, (Soldaki resim).

Görsel 2. Ellen Altfest, The Back, 2008-2009, Tuval Üzerine Yağlıboya, $40.6 \times 63.5 \mathrm{~cm}$

(Sağdaki resim).

Her iki eser de dönemsel ve biçimsel olarak; eserdeki plastik etkiler ve ifade yönelimleri bakımından farklılık gösterir. Praxiteles'in Knidos Aphroditesi'nin sanat tarihinde önemli bir yeri ve anlamı vardır.

Knidos Aphroditesi heykelinin ilk olarak Praxiteles tarafından kariyerinin zirvesinde olduğu M.O. 360-330 yılları arasında Knidos'daki Aphrodite tapınağının kült heykeli için yapıldığı ileri sürülmektedir. Orijinali günümüze kadar ulaşamamış olan heykel, Knidos'ta ele geçen Roma dönemi sikkeleri ile bir seri halinde çoğaltılan kopyalarından bilinmektedir. Bu heykel tamamen çıplak ve kült heykeli olarak kullanılan ilk Aphrodite heykeli olması açısından önem taşımaktadır (Dinç, 2016, s.86).

Bu eser; kadın imgesinin estetik yapısı ile form ilişkisine açıklık getirmesi bakımından önemlidir. Heykelin oran ve orantısındaki sağlamlıkile perspektifin yapısal düzenlenişi oldukça etkilidir. Heykelde estetik bir duruş vardır. Başın hafif dik olması, bedenin yapısal formuna sağlamlık katmaktadır. Bu durum sanatta bir yeniliktir. "Praksiteles'in kazandırdığı en büyük yeniliklerden birisi de, heykellerin duruşlarının izleyiciye yansıttığı rahatlık ve yumuşaklıktır. Artık poz verircesine güzelliğini veya kas gücünü göstermek yerine, heykellerin kendi içlerindeki huzurlarının ve sadeliklerinin 
yansıması tercih edilir" (Durugönül, 2018, s.100).

Eser, geçmişten günümüze estetik yapının farklı ve benzer yanlarının karşılaştırıması bakımından da önem taşımaktadır. Bu durumun, izleyicide güzellik olgusunun değişiminde etkili olduğu söylenebilir.

Ellen Altfest'in The Back isimli eserinde, koltuğa uzanan bir çıplak figür dikkati çekmektedir. Figürün bedeni biçimsel olarak rahat bir pozisyonda olup temsili gerçeklikte bir aktarım yapılmıştır. Dolayısıyla Altfest'in gerçekçi dili, bedende psikolojik bir etki yaratmıştır. Çünkü sanatçının nesneler üzerindeki kurgusu; eserlerindeki detaylarda saklıdır. Sanatçı eserlerinde doğadan belirli kesitleri yakalayarak; daha çok detayları ele almaktadır. Bedenin sırt ve boyun kısmındaki kılların detaylandırıması; izleyicide estetik beğeninin yitimine sebep olmuştur. Ancak Knidos Afroditi'nde böyle bir durumdan söz edilemez. Çünkü bedenin duruşundaki ve dokusundaki estetik yönelim; izleyicide kusursuz bir model imgesi sunmaktadır. Böylece dönemsel olarak; sanattaki yaklaşımlar ile estetik yönelimler farkllık gösterebilmektedir. Bu durum sanatta estetik algıların zaman içerisinde değişimine ve gelişimine bir kanıttır.

\section{Lucian Freud'un ve Ellen Altfest'in Eserlerindeki Benzerlikler}

İngiliz ressam Lucian Freud'un erken dönem eserleriyle Ellen Altfest'in eserleri arasındaki benzerlikler dikkat çekicidir. Freud'un natürmortlarındaki ekspesif ve realist aktarımları ile deformasyonları benzerlik gösterir. Her iki sanatçının nesne çözümlemelerinde; kişileştirme ve psikolojik yönelim bulunmaktadır. 

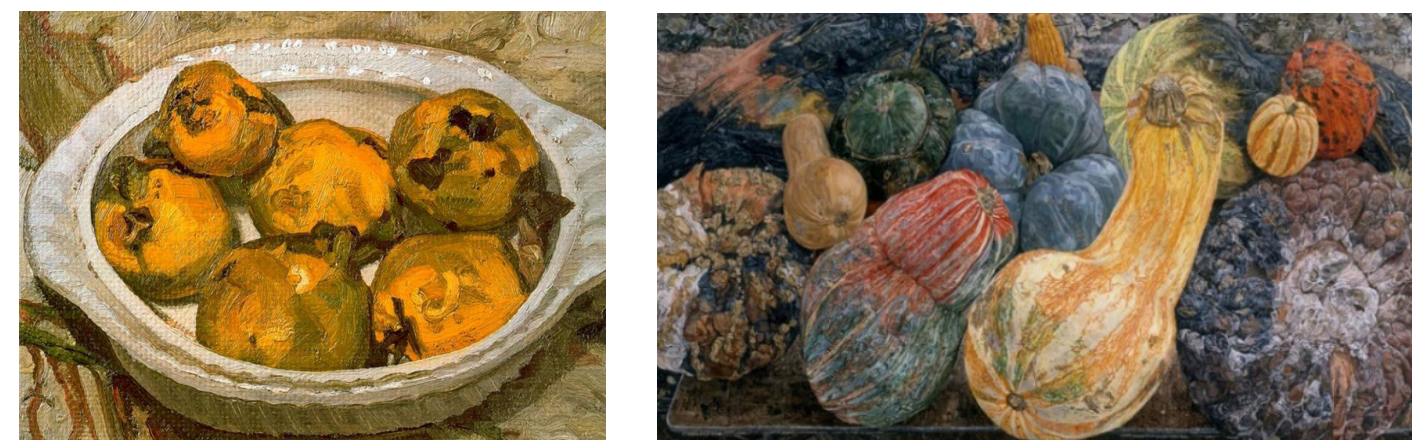

Görsel 3. Lucian Freud, Ayvalar, 1981-1982, Tuval Üzerine Yağlıboya,

$$
21 \times 16 \mathrm{~cm} \text { (Soldaki resim). }
$$

Görsel 4. Ellen Altfest, Kabaklar, 2006-2007, Tuval Üzerine Yağlıboya, 48.3 x 96.5 cm),

Private Collection, Photo: Bill Orcutt, New York (Sağdaki resim).

Örneğin; Frued Ayvalar isimli eserindeki nesnel gerçekliği psikolojik bir boyutta sorgulamıştır. Bu bakımdan sanatçının eserlerinde deformasyona başvurması; onun dışavurumcu yöneliminden kaynaklanmaktadır. Ayvalar gerçekçi bir üslupla ele alınmıştır. Ancak rahat fırça vuruşları, kavramsal dil ve biçim ilişkisi ve tuvalden bağımsız olarak kompozisyonların oluşturulması; sanatta temsil olgusuna farklı bir boyut kazandırmıştır.

Ellen Altfest'in Kabaklar isimli eserinde ise hiperrealist bir oluşum dikkati çekmektedir. Kabakların her ayrıntısı düşünülmüş ve temsiline uygun şekilde aktarımıştır. Ellen Altfest eserleri ile ilgili şunları söylemektedir:

Kayalar, kütükler ve kabakların evvela çok az işlevleri olduğu için, üzerlerine her ne yansıtılırsa, iyi birer depo haline geliyorlar. Doğal ortamlarından uzaklaştııımışlardır ve benim deneklerim olarak hizmete sunulmuşlardır, kabakları seçtim çünkü cinsel formları erkek çıplaklığıyla uyumlu oldu, ama çürüme, bu tuval üzerindeki kendi dramlarının bir parçasıydılar (Aho, 2010, s.41).

Sanatçının düşüncesinden açıkça anlaşılmaktadır ki, eserlerindeki kabaklar erkek bedenlerin temsili formlarıdır. Dolayısıyla sanatçı, iki farklı yapıyı (nesne ve özne; kabak ve insan) karşılaştırarak; onların doğadaki formlarının benzerliklerine dikkat çekmiştir. Bu yüzden eserlerindeki hiperrealist aktarımı; nesneler ve özneler 
arasında bir dönüşüm olarak kullanmıştır.

Freud'un Ayvalar'ından daha gerçekçi ve rengin nitelikleri ön plandadır. Bu yaklaşım biçimi fotoğrafın gerçekliğine bir meydan okuma olarak algılanmamalıdır. Doğanın yaşam karşııındaki formuna, döngüsüne ve ilişkisine bir gönderme olarak düşünülebilir. Eserinde doğanın zaman içerisinde bozulmasına, çürümesine ve değişimine bir yorum getirmiştir. Resimde nesnenin ilk hali ile son halinin geçirdiği evreler görülmektedir. Zaman ve ölüm arasındaki bağın doğayla özdeşimi kurulmuştur. Altfest bu özdeşimi; toplum ve birey ilişkisine de taşımıştır. 2010 yılında yapmış olduğu Baş ve Bitki isimli eserleri bu duruma örnek olarak gösterilebilir.
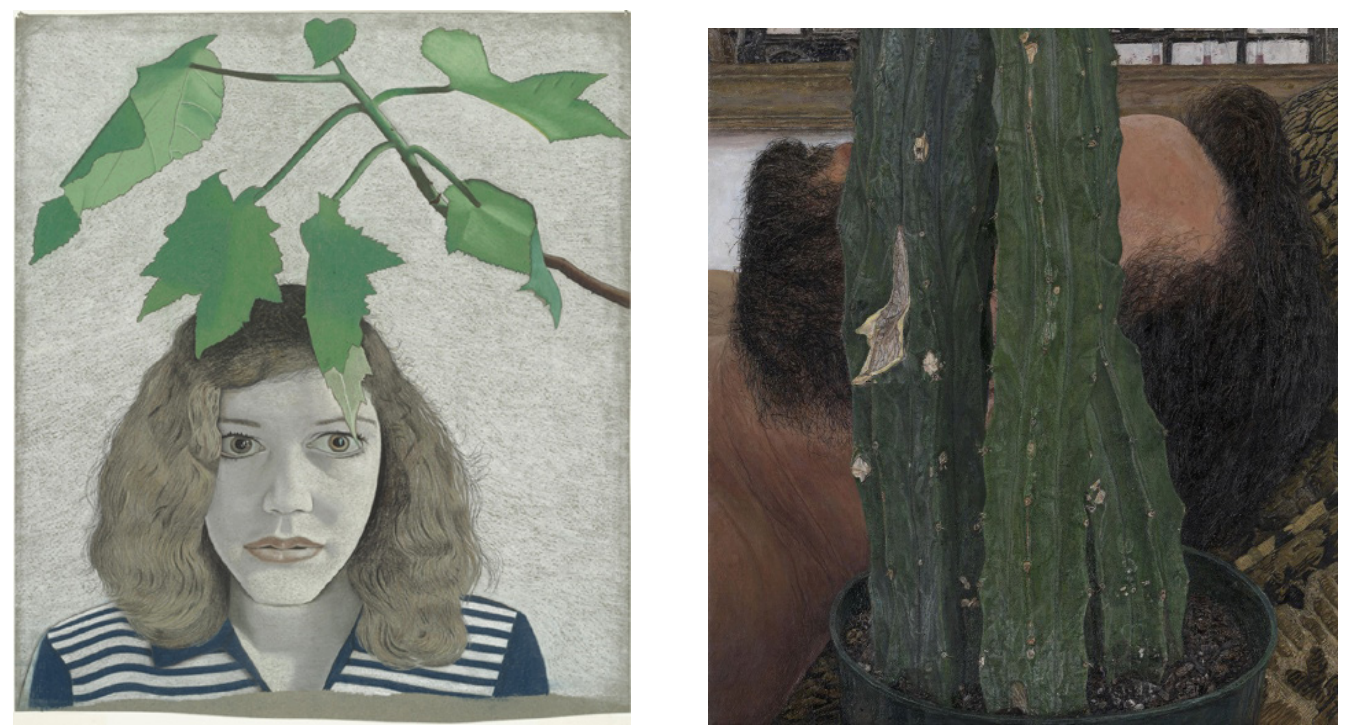

Görsel 5. Lucian Freud, Yaprakları ile Kız, 1948, Kâğıt Üzerine Pastel (Soldaki resim).

Görsel 6. Ellen Altfest, Baş ve Bitki, 2010, Tuval Üzerine Yağlıboya, 27.9 c 25.4 cm, Courtesy the artist and White Cube, London, Photo: Todd-White Art Photography (Sağdaki resim).

Lucian Freud'un Yaprakları ile Kız (1948) ve Ellen Altfest'in Baş ve Bitki (2010) isimli eserleri benzer kavramsal düşünceleri içerir. Farklı zamanlarda yapılmış olan eserlerde; melankoli, buhran, içe yönelim ve düşünce sancısı öne çıkmaktadır. "Freud, tablolarının dikkatlice gözlemlediği insanlar gibi değil, onlar hakkında olduğuna inanırdı. Ancak, bazıları tablolarının melankolik gerçekçiliğinin onun konu ettiklerini yansıtmasındansa insanlık hakkındaki görüşleri hakkında bilgilendirdiğini 
öne sürmüşlerdir" (Harris, 2013, s.455). Dolayısıyla Freud'un eserlerindeki melankolik gerçek; toplumla ilişkilidir. Yaprakları ile Kız isimli eserinde de benzer ifade ve düşünce yapısıyla oluşturduğu gözlemlenmiştir.

Freud eserindeki kızın donuk ve ifadesiz bakışını; yapraklar ile gizlemiştir. Benzer düşünceyi Altfest eserinde; başı ve kaktüsü bir araya getirerek uygulamıştır. Freud'un aktarımı daha açık ve anlaşılırken; Altfest'in düşüncesi daha kapalı ve kavramsaldır. Bu yüzden Altfest'in eserindeki yüzün kimliği belirsizdir. Eserin kompozisyonu bağımsızdır ve detay olarak kurgulanmıştır. Bu durum esere gizem katmıştır; eserde nesne ile öznenin karşılaştırılması yapılmıştır. Aynı zamanda bireyin kimlik ve teşhir olgusuna yönelik bir eleştiride bulunulmuştur. Bu yüzden yüz, bilinçli olarak gizlenmiştir. Sanatçının temsil olgusunu (eleştiriye yönelik) sanatta bir araç olarak kullandığı ortaya çıkmaktadır.

\section{Nesnelerin Temsili: "Taş, Ayak, Bitki", “Koltuk Altı" ve “James"}

Ellen Altfest'in 2009 yılında yapmış olduğu Taş, Ayak, Bitki isimli eserinde; farklı doğal nesnelerin her bir ayrıntısı incelikle resmedilmiştir. Bu eserde hem doku hem de ifade ön plandadır. Her biri farklı nesnelerdir; ancak eserin ifadesi ve ruhsal durumu ortak bir paydada kesişmektedir. Resim bir doğa çözümlemesidir; aynı zamanda eserde bir insanın uzvu resmedilerek ruhsal bir durum ortaya konulmuştur. Böylece nesnelere bir anlam ve kavram yüklenmiştir. 


\section{$\operatorname{arts}=$}

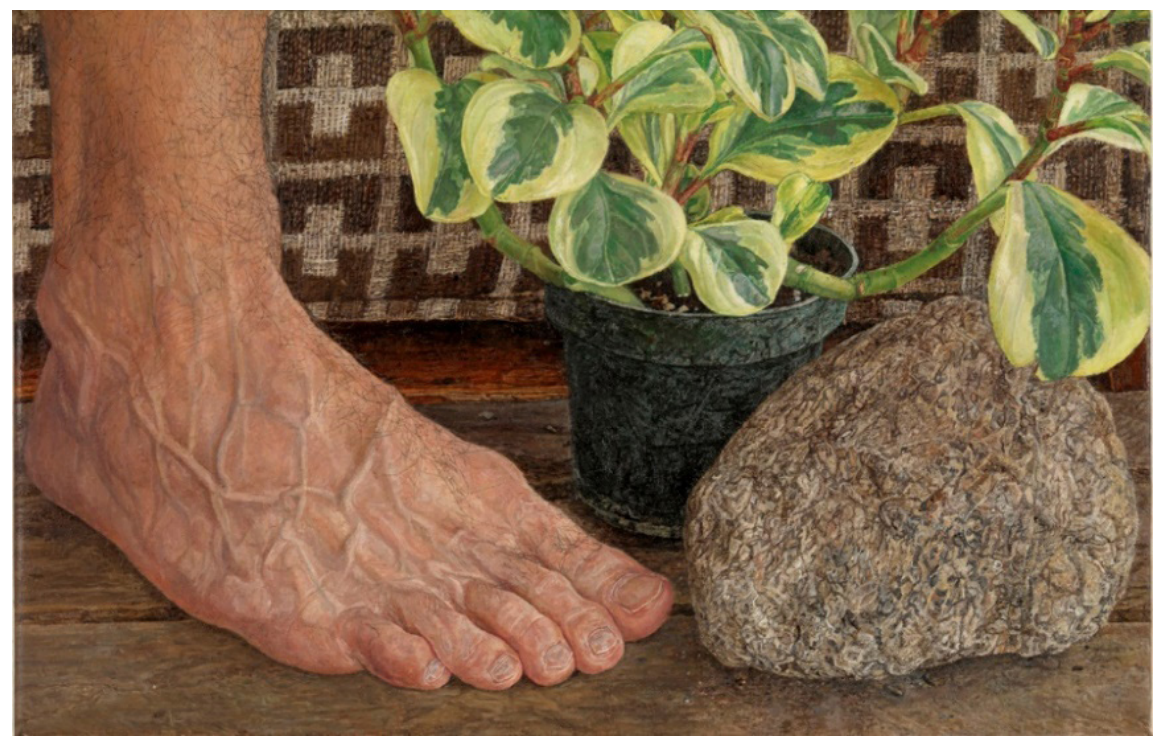

Görsel 7. Ellen Altfest, Kaya, Ayak ve Bitki, 2009, 22.9 x 35.6 cm, ONE2 Collection, USA. Photo: Todd-White Art Photography. Image courtesy White Cube @ Ellen Altfest / White Cube.

Altfest bu resminde temsil durumunu; birey ve doğa ilişkisiyle ele almıştır. Baş ve Bitki isimli eserindeki gizleme yöntemi; bu eserinde de (Görsel 7.) uygulanmıştır. Bedenin geri kalanı gizlenmiş ve ayak üzerinden bireyin kişiliği ortaya çıkarılmıştır. Dolayısıyla bireyin etrafındaki nesnelerin; onun ruhsal durumuyla ilişkilendirildiğini gösterir. Eserlerindeki hiperrealist yönelim; nesne ve bireyin çözümlemesini ele aldığı içindir. Bu yüzden sanatçının eserlerinde, geleneksel ifade dilinin dışında bir anlatım yöntemine neden intiyaç duyduğu anlaşılmaktadır. Çünkü Altfest nesneleri kavramsal bir zemine oturmak istemektedir; bu nedenle kompozisyonun açılarını değiştirerek detayları ele almaktadır. Eser ebatlarını çoğu kez küçük tutarak; izleyiciye detayların önemini vurgulamaya çalışmaktadır. Sanatçı eserlerinde günlük yaşamdaki nesneleri; doğal ve anlık bir kurguyla ifade etmektedir.

Altfest'in boyadığı nesneler (ağaç kabukları, saksıda bitkiler, yosun, kumaş, kıllar) günlük yaşamda göz ardı edilir, ama gözlemlenen gerçekliğe dair canlı ve dikkatli yorumlamaları bize bir duraksama vermekle kalmaz, ama aynı zamanda çevremizdeki dünyanın sonsuz karmaşasına ilkel bir takdiri yeniden oluşturur, özellikle de doğal yaşamda (Goodwin, 2019, s.124).

Sanatçıyı çağdaşlarından ayıran önemli bir fark ise; eserin bir doğa çözümlemesinin ötesinde ruhsal ve düşünsel bir yanının olmasıdır. İnsanoğlunun doğal 
yaşamdaki ilkel yanını göstermek için; nesneler ile insan bedenlerini karşılaştırdığı ileri sürülebilir.

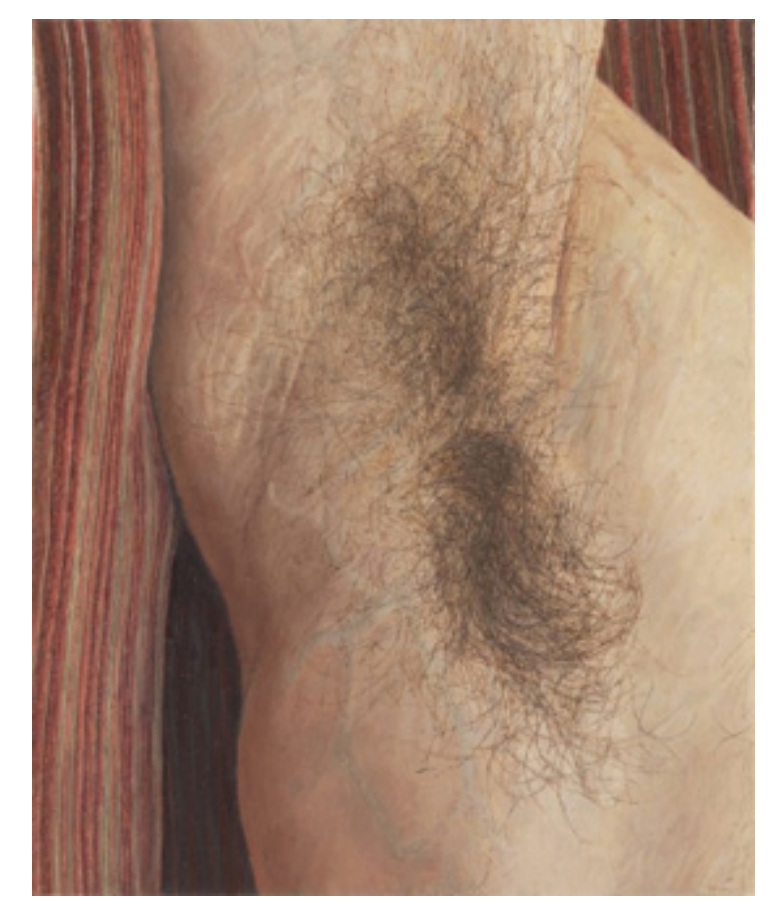

Görsel 8. Ellen Altfest, Koltuk Altı, 2011,21.2 x $17.8 \mathrm{~cm}$, Tuval Üzerine Yağlıboya,

Courtesy of the artist and the gallery.

Sanatçının Koltuk Altı isimli ve 2011 yılı yapımlı eseri oldukça küçük ebatıdır. Eserinde insanın mahrem alanını sorgulayarak eleştirmiştir. İnsan bedenin gizil bölgelerinin detaylandırılarak resmedilmesi sıra dışı bir durumdur. Kılların her bir detayının incelikle yapılmasıyla ve kapalı alanın gösterilmesiyle birlikte; toplumsal bir yapının sorgulandığı anlaşılır. Tıpkı Kaya, Ayak ve Bitki'de olduğu gibi bedenin çıplaklığı üzerinden; birey ve kimlik ilişkisi incelenmiştir. Cinsiyet, beden, çıplaklık, kimlik ve kodlar; toplumun birey üzerinde uyguladığı normlar olabilmektedir. Bu bakımdan baskı altında kalan bireylerin kendilerini ifade edebilmeleri de pek mümkün olmamaktadır. Eser, toplumsal normları ele alması bakımından güncel ve eleştireldir. Sanatçının diğer serilerinde olduğu gibi bu eserinde de ifadeyi küçük ebatlı bir tuvalde detaylandırması; izleyiciyi eserin anlamı üzerinde yoğunlaştırmasından kaynaklanmış olabilir. 


\title{
arts $=$
}

Sanatçının eserlerinde figüratif bir eğilim dikkati çekmektedir. Bu durumun iki önemli nedeni olabilir: İlki figüratif resimle toplumda kişileri ortaya çıkarmak ve eleştirmektir. Diğeri ise; figürlerle nesnelerin ortak yönlerini ortaya çıkararak anlatımsal bir ifadeye ulaşmaktır. Eserlerinde öne çıkan figüratif ve anlatımsal eğilime ilişkin şu cümleleri önemlidir:

İşlerimi tanımlamak için bir kısaltma olarak "figüratif ressam" terimine itirazım yok. Ucu daha açık göründüğünden 'anlatımsal' terimini kullanmaya eğilimliyimdir. Isşlerimin daha kişisel veya kendine has bir bakış açısını yaymak ile ilgilii olduğunu düşünüyorum. Figüratif bir ressam olma nedenim tablolarımın daha kolay anlaşılmasını sağlama arzusu muydu? Hayır. Tanınma ve ulaşılabilirlik farklı şeyler. Ben, tanımlanmış bir yorumlaması olmayan bir şey yaratmakla ilgileniyorum. Eserimin izleyiciyi yavaşlatıp kavrayış anını geciktirmesini istiyorum (Higgie, 2014, s.95).

Aynı zamanda, izleyiciyi güncel sorunlar üzerinde düşündürerek eleştirisini göstermektedir. Sanatçı konularını seçerken de oldukça mütevazı davranmakla birlikte; eserlerini uzun bir sürede gerçekleştiriyor.

\begin{abstract}
Ellen Altfest, sanata olan yaklaşımına "aktif dayanıklılı" adını veriyor-sadece hayattan resim yapıyor, genellikle her saatte beş dakikalık bir arayla, yedi saatlik artışlar halinde çalışıyor, ve bir tabloyu yedi ayda bitiriyor. Keskin bir şair olarak, Altfest'in mütevazı konuları, ister şekilsiz bir kabağın üzerindeki kabuklar kümesi olsun, ister skrotumun büzüșmüs derisinin sınırlarındaki kıvrılmış kıllar manzarası olsun, tuval üzerinde zarif ve çekinmeyen detaylarıyla ortaya çıkar (Xu, 2019, s.96).
\end{abstract}

Bu yüzden Altfest'in temsil ettiği nesneler; estetik beğenin ve geleneksel formlarının dışındadır. İzleyiciyi normal algının dışında bir algılamaya yönlendirmesi; eserindeki detaylardan ileri gelmektedir. Dolayısıyla onun sanat algısı, tıpkı Chuck Close gibi fotorealizmin ötesindedir. 


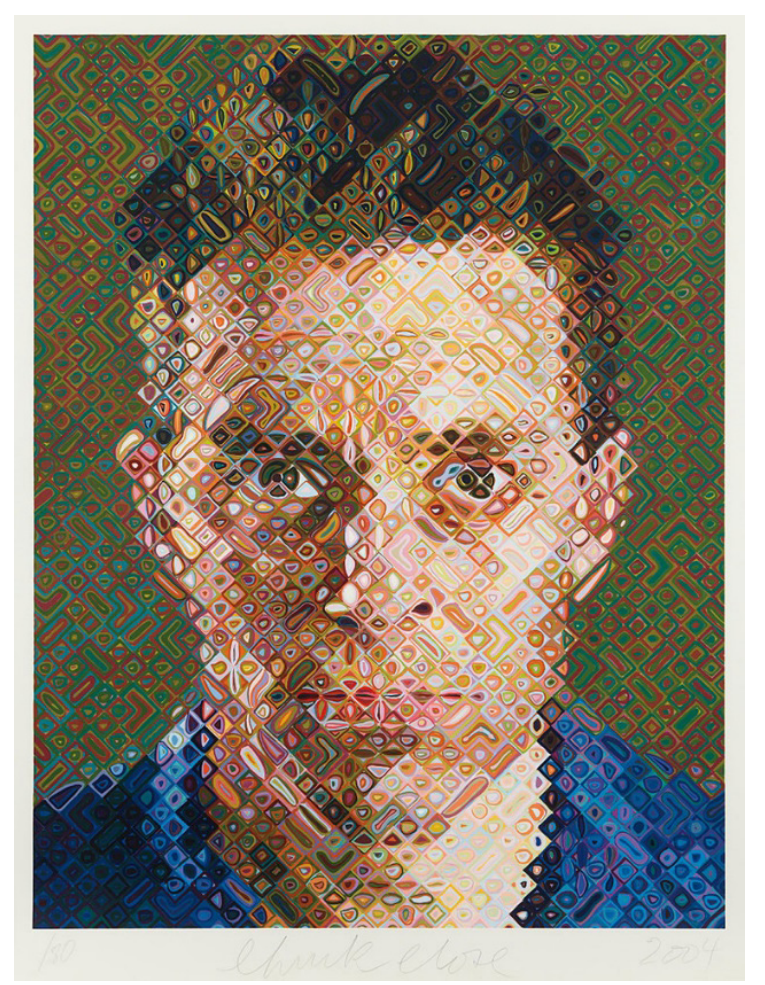

Görsel 9. Chuck Close, James, 2004, $176.5 \mathrm{~cm} \times 138.1 \mathrm{~cm}$,

Tuval Üzerine Yağlıboya.

Chuck Close; Lucian Freud'un ve Ellen Altfest'in ifade dilinden farklıdır. Ancak ortak noktaları; temsiliyettir ve kişilerin ruhsal analizini yapmaktır. Chuck Close'un eserlerindeki fotorealist aktarımı; konu ve teknik ilişkisi bakımından ele alınmalıdır. "Fotoğraflarını bazen portreleri için temel olarak kullandığından, Close'un yaklaşımı bazen Foto-Realistlere benzetilebiliyor, ancak yaratıcı süreç boyunca yaklaşımı farklılaşabiliyor. Gerçekten de konusu tekniğinin yanında hep geri planda kalıyor" (Johnson, 1992, s. 18).

Close'un ele aldığı portreleri sabittir ve durağandır; değişken bir özellik göstermezler. Ancak sanatçının tekniği, yaratıcı sürecine katkıda bulunduğu iddia edilebilir. Bu yüzden eserlerindeki ifadeler güçlüdür. Bunun yanında Ellen Altfest'in Baş ve Bitki ve Chuck Close'un James isimli eserlerinde gizleme ve kapalı bir anlam vardır. Eserde renk, biçim ve şekiller ile portre yapıbozuma uğratılmıştır. Close'un eserlerinde fotoğrafın piksel birimleri gibi bozulmalar dikkati çeker. "Tıpkı bunun gibi, Close'un resimlerine uzaktan bakan biri, renk geçişlerini son derece yumuşakmış 


\section{$\operatorname{arts}=$}

gibi algılar; oysa yakından baktığında saf renk noktalarını net bir şekilde görür." (Yılmaz, 2013, s.263). İzleyici eser karşısında gözünü kırptığında net bir görüntü elde etmektedir. Sanatçının ifade dili ve üslubu farkı olsa da konuya yaklaşım biçimleri Altfest ile benzerlik gösterir. Altfest küçük ebatlı resimlerinde detaylandırmaları ele alırken; Chuck Close ise büyük ebatı resimlerini uzak mesafede algılatmaktadır. Ellen Altfest'in eserlerindeki bir diğer farklılık ise; kompozisyonların gelişigüzel bir şekilde kurgulanmasıdır.

Ellen Altfest'in tablolarında gelişigüzel görünen bir şey var. Gerçekçilikleri rüzgarda sürüklenen çalıların veya dalgaların kıyaya sürüklediği yosun kaplı odunların ufak ayrıntılarını yakalamaya uğraşsa da, sanatçının olağanüstü teknik becerileri fotografik bir hassasiyetle tespit ederken, bir şey boyanın maddesel kavrayışından, tuvalin resmi eksikliklerinden, gözün algısal kapsamından kaçar. BU gelişigüzellik belki de gerçekliğin kendi fonksiyonlarından biridir, Rolan Barthes'in 'gerçeklik etkisi' adını verdiği modern bir fenomen -tesadüfi veya rastgele detayın tanımlanmış (veya Altfest'e göre, tasvir edilmiş) bir sahneyi 'gerçekliğin' tamamına etki ettiren, ki bu, bir eseri sanatçının orada oluşuna, o anda, gözlerimizin önünde bu manzaraya tanıklık etmiş olduğuna dair bir kanıt olarak sabitler (Ho, 2006, s.117).

Eserlerindeki gelişigüzellik, izleyicide bir yanılsama meydana getirmiştir. Bu yanılsamayla birlikte izleyici; sanatçı ve eseriyle aynı ana tanıklık eder. Dolayısıyla gerçeklik algısı yaratılmış olur. Böylece Altfest'in eserlerinde neden kesitler ve bölümler halinde bir kompozisyon kurgusuna başvurduğu anlaşılmışır.

\section{SONUÇ}

Ellen Altfest'in eserleri geçmiş ve güncel sanatçıların eserleri ile karşılaştııldığında; resimlerindeki estetik yapılanmada farklılıklar gözlemlenmiştir. Sanatın tarihsel sürecinde bu yapılanmanın; izleyicinin algısıyla ve sanattaki dönüşümle doğrudan ilişkili olmuştur. Bu yüzden sanatta temsil olgusu ile estetik yapı arasında paralellik bulunduğu iddia edilebilir.

Temsiliyet her sanatçıda olduğu gibi Ellen Altfest'in eserlerinde de bir ifade aracı olmuştur. Sanatçının bu kavramı, eserlerinde psikolojik etkileri ortaya çıkarmak için kullandığı fark edilmiştir. Dolayısıyla hiperrealizm görüntünün bir kopyası değil; düşüncenin ve kurgunun sanattaki yansıması olarakifade edilmiştir. Onun resimlerinde görüntünün ve imgenin gerçeklik kavramı ile ifade edilmesinde; kompozisyonun 
önemli bir yanının olduğu tespit edilmiştir. Çünkü kompozisyon; sanatçı, izleyici ve eseri bir araya getiren bir düzlemde kurgulanmıştır. Bu yüzden izleyici eserlerinde ana tanıklık ederek, sanatçı ve eserini bir arada gözlemleyebilmiştir.

Sonuç olarak Ellen Altfest, küçük ebatı ve detay resimlerini; kavramsal bir ilişkide ele alıp sorgulamıştır. Bu sayede izleyici detay olarak gördüğü resimlerde; yeni bir yorum getirme imkanı yaratabilmiştir. Sanatçıyı diğer çağdaşlarından ayıran fark bu olmuştur. Araştırma kapsamında güncel sanatın yeni ve farklı dinamiklerini toplum ve doğa ilişkisi bakımından ele alıp eleştiren önemli bir sanatçı olduğu anlaşılmıştır.

\section{KAYNAKÇA}

Aho, E. (2010). Meeting of Minds. Modern Painters, 22 (1), 41.

Dinç, M. (2016). Tarsus Müzesi Taş Eserleri Heykeltıraşlık ve Mimari Plastik Eserler. S. Durugönül (Ed.). İstanbul: Tarsus Ticaret ve Sanayi Odası Tarsus Ticaret Borsası Yayını, 86.

Durugönül, S. (2018). Heykeller Konuşabilseydi... Antik Yunan Heykeltıraşlık Sanatına Toplumsal Açıdan Bir Bakış. Ankara: Bilgin Kültür Sanat Yayınları.

Goodwin, C. (2019). The Art of Concentration. Modern Painters, 31 (3), 124.

Gök, C. (2016). Değişen İmgeler ve Temsiliyet. İstanbul Kemerburgaz Üniversitesi Sosyal Bilimler Dergisi, Sayı (2), Cilt 1, 116.

Harris, J. C. (2013). Lucian Freud's reflection (self-portrait). JAMA Psychiatry, 70(5), 455.

Higgie, J. (2014). 8 Painters on Painting. Frieze, (160), 95.

Ho, C. K. (2006). Ellen Altfest: Still Lives. Modern Painters, 117.

Johnson, M. M. (1992). Chuck Close: Editions. Arts \& Activities, 111 (4), 18.

Sherlock, A. (2015). Ellen Altfest. Frieze, (173), 177. 


\section{arts}

Yılmaz, M. (2013). Modernden Postmoderne Sanat. İstanbul: Ütopya Yayınevi.

Xu, T. (2019). Ellen Altfest at White Cube Hong Kong. Modern Painters, 31 (1), 96.

\section{GÖRSEL KAYNAKLAR}

Görsel 1. Praxiteles'in Knidos Aphroditesi, M.Ö. 360-330.

Erişim: 23.12.2019. http://zone47.com/crotos/ $/=p l \& p=\& n b=20 \& d i s p=1 \& s=$ $\& y 1=-40000 \& y 2=2016 \& p 31=\& p 144=2858262$

Görsel 2. Ellen Altfest, The Back, 2008-2009, Tuval Üzerine Yağlıboya, $40.6 \times$ $63.5 \mathrm{~cm}$.

Erişim: 24.12.2019. https://www.artsy.net/artwork/ellen-altfest-the-back-1

Görsel 3. Lucian Freud, Ayvalar, 1981-1982, Tuval Üzerine Yağlıboya, 21 x16 $\mathrm{cm}$ (Soldaki resim).

Erişim: 24.12.2019. wikiart.org/en/lucian-freud/still-life-quinces-1982

Görsel 4. Ellen Altfest, Kabaklar, 2006-2007, Tuval Üzerine Yağlıboya, 48.3x $96.5 \mathrm{~cm}$ ), Private Collection, Photo: Bill Orcutt, New York (Sağdaki resim).

Erişim: 25.12.2019. https://wsimag.com/art/14158-ellen-altfest

Görsel 5. Lucian Freud, Yaprakları ile Kız, 1948, Kâğıt Üzerine Pastel (Soldaki resim).

Erişim: 26.12.2019. https://www.moma.org/explore/inside_out/2011/08/29/ lucian-freud-in-memoriam/

Görsel 6. Ellen Altfest, Baş ve Bitki, 2010, Tuval Üzerine Yağlıboya, 27.9 c $25.4 \mathrm{~cm}$, Courtesy the artist and White Cube, London, Photo: Todd-White Art Photography (Sağdaki resim).

Erişim: 26.12.2019. https://www.newmuseum.org/calendar/view/1/artisttalk-with-ellen-altfest

Görsel 7. Ellen Altfest, Kaya, Ayak ve Bitki, 2009, $22.9 \times 35.6 \mathrm{~cm}$, ONE2 Collection, USA. Photo: Todd-White Art Photography. Image 
courtesy White Cube (c) Ellen Altfest / White Cube.

Erişim: 28.12.2019. https://eclecticlight.co/2015/07/02/the-body-realpaintings-by-ellen-altfest-and-a-book-review/

Görsel 8. Ellen Altfest, Koltuk Altı, 2011, $21.2 \times 17.8 \mathrm{~cm}$, Tuval Üzerine Yağlıboya, Courtesy of the artist and the gallery.

Erişim: 29.12.2019. http://www.initiartmagazine.com/gallery. php?galleryid $=74 \&$ date $=1325656047$

Görsel 9. Chuck Close, James, 2004, $176.5 \mathrm{~cm} \times 138.1 \mathrm{~cm}$, Tuval Üzerine Yağlıboya.

Erişim: 30.12.2019. https://www.masterworksfineart.com/artists/chuck-close/ screen-print/james-2004/id/W-4588 